\title{
Entrepreneurial Strategies and Factors Stimulate the Business of Tech Startups
}

\author{
Venkata Sai Srinivasa Rao Muramalla ${ }^{1}$ \& Ateeq Mesfer Al-Hazza ${ }^{2}$ \\ ${ }^{1}$ Venkata Sai Srinivasa Rao Muramalla, Prince Sattam Bin Abdulaziz University, Saudi Arabia \\ ${ }^{2}$ College of Business Administration, Prince Sattam Bin Abdulaziz University, Saudi Arabia \\ Correspondence: Venkata Sai Srinivasa Rao Muramalla, Venkata Sai Srinivasa Rao Muramalla, Prince Sattam Bin \\ Abdulaziz University, Saudi Arabia.
}

Received: April 20, 2019

Accepted: May 7, 2019

Online Published: May 19, 2019

doi:10.5430/ijfr.v10n3p360

URL: https://doi.org/10.5430/ijfr.v10n3p360

\begin{abstract}
Enterprising a startup business is depending on personal experiences of investors and their social relationships with all stockholders. Startup entrepreneurs are typically involved in the qualitative evaluations of their business counterparts operating in the market. However, startup entrepreneurs shall look at what caused them to fail in their ventures, they examine the reasons for their failures, and finally, entrepreneurs develop a culture of strategic thinking for getting success in the business. In this context, this paper examined the entrepreneurial strategies of tech startups and deliberated the factors that stimulate the growth of a tech startup business in India. However, initiatives of the government to promote tech startups in India also exposed in this paper.
\end{abstract}

Keywords: angel investors, digital economy, entrepreneurs, enterprising, strategies, tech startup

\section{Introduction}

Strategic approach of entrepreneurs is indispensable for the economic growth of a country (Eschenfelder \& Holstein, 2017). Indeed, the primary reasons of capitalists for enterprising of startups are such as for their self-realization to own a business, for relishing independence in business decision making, for economic reliance, for recognition and status in the society, and for demonstrating capabilities of employing the innovations and building of large establishments or corporations (Lasso, Mainardes, \& Motoki, 2017). Eventually, the investment of startup industrialists has depended on their personal experiences as financiers of enterprises and their social relationships with all stakeholders in the industry as well as their qualitative evaluations of firms operating in the market (Okafor \& Shaibu, 2016; Bugu \& Yucheng, 2018; Zhong, Liu, Zhong, \& Xiong, 2018).

However, the close examination of the failures of startups in India usually bears that things do not go with the efforts of entrepreneurs according to the planning of a startup business (Bouvier, 2016). Subsequently, the startup capitalists were giving up after the failures in their ventures (Rey, 2013) which were possibly the worst choice that they might choose before to find the successful business opportunities (Scarmozzino, Corvello, \& Grimaldi, 2017). Indeed, feeling sorry about this kind of choices will not bring success to the entrepreneurs. Because businesspersons need to look at what caused them to fail (Baloff \& McKersie, 1966) and they should minimize the sources for such failures by avoiding such things ever to happen again. This workout will stretch the confidence of entrepreneurs to focus on how to increase the chances of their success in the tech startup business (Hulme, 2010). Alternatively, to enhance the differentiation from other players in the market, tech startups have to develop a culture of strategic thinking for success (Wye \& Lim, 2014; Isimoya, 2014; Iyiola, 2014; Maldonado-Guzman, et.al. 2018; Agbim \& Eluka, 2018; Udanoh \& Zouria, 2018Sinha, 2008).

In this context, this paper discussed the initiatives of the Indian government to promote the tech startups and analyzed the strategic approach of tech startup entrepreneurs in India by speak out the factors that stimulate the tech startup business in the country.

\section{Government Initiatives to Promote the Tech Startups}

Even though India has the largest ecosystem for startups after the United States of America (USA) and the United Kingdom (UK), $90 \%$ of Indian startups were failures because of lack of strategic thinking combined with the deficiency of technological innovations and the absence of unique business models (Prashantham \& Yip, 2017). The 
industry also added it reports that the majority of tech startups was failed in India because of deficiency of inventions and counterfeit of Western ideas in technologies (Team Inc42, 2018). Suffice to mention that no Indian enterprise was among the top companies in the world that applied for patents in technologies during the financial year 2017 (FY17) (WIPO, 2018). Among the top ten companies that applied for patents in technologies, the highest number of applications was filed by the two China-based companies namely Huawei Technologies (4,024 applications) and ZTC Corporation (2,965 applications) followed by Intel Corporation of USA (2,637 applications) and Mitsubishi Electric Corporation of Japan (2,521 applications). Though, Indian startup enterprises were applied 909 applications for patents in technologies during the FY17 (Rajesh Kurup, 2018) which is an increase of 10\% over the previous year (Balaji, 2017).

However, the Government of India has been promoting free enterprise in the tech startup business by the establishment of software technology parks, development of special economic zones, creation of industrial corridors, conception of the task force for e-Governance, and implementation of cybersecurity policies for Information Technology (IT) industry. The cities in India that attracted majority tech startups are Bangalore, Hyderabad, Chennai, Pune, and Kolkata. Another three cities namely Kerala, Jaipur, and Chandigarh also emerging as tech startup hubs in India. The Indian government is providing incentives for technology exports (Makeinindia.com, 2018). The government has been spending nearly $\$ 1.6$ billion annually on the training of tech-based workforce as well as funding the technology research institutes to encourage innovations in the country. Table 1 shows the tendency of the Indian government in funding the tech startups during FY17\&FY18. However, the infusion of cash for technological innovations in a country would safeguard the entrepreneurs to introduce the new technologies and commercialize the inventions (Madden, 2005).

Table 1. Trends in government funding for tech startups in India

\begin{tabular}{lllll}
\hline Funding details & 2017 (Jan-Sept) & $2018(\mathrm{Jan}-\mathrm{Sept})$ & Change & Inc.(or) Dec. \\
\hline Total Funding & $\$ 2.0 \mathrm{bn}$ & $\$ 4.2 \mathrm{bn}$ & $108 \%$ & Increase \\
\hline No. of Deals & 529 & 451 & $15 \%$ & Decrease \\
\hline Avg. Funding & $\$ 43.9 \mathrm{mn}$ & $\$ 49.4 \mathrm{mn}$ & $144 \%$ & Increase \\
\hline Seed Stage & $\$ 4191 \mathrm{mn}$ & $\$ 4151 \mathrm{mn}$ & $21 \%$ & Decrease \\
\hline Early Stage & $\$ 4993 \mathrm{mn}$ & $\$ 41.0 \mathrm{bn}$ & $4 \%$ & Increase \\
\hline Late Stage & $\$ 4847 \mathrm{mn}$ & $\$ 3 \mathrm{bn}$ & $259 \%$ & Increase
\end{tabular}

Source: (NASSCOM, 2018b)

The supplementary initiatives of Indian government to promote the tech startups are such that the enactment of national policy on technology that aims to fetch the progress of information and communication technology (ICT) in the country to reach the whole of India and to deploy the human resources to become a global hub for IT services (Meity.gov.in, 2012). Besides, the government is also encouraging the private sector participation in the technology industry to capture a substantial portion of global technology sourcing business from the current share of $56 \%$ worldwide. This collaborative approach of the government to promote the IT industry will make the country a trillion-dollar digital economy. Also, the government of India is looking forward to contributing 15 to $20 \%$ of global gross domestic product (GDP) by attaining the critical mass of startup business movement in the country (Badra, Dr.Shailja, \& Sharma, 2016). Let us discuss the strategic approach of tech startup entrepreneurs in India in exploiting the encouragement of the government

\section{Entrepreneurial Strategies of Tech Startups}

The success of any startup is mainly subjective to greater creative thinking and the capabilities of team members operating the enterprise aside the strategic partnerships with novel investors and suppliers, pricing policies, an assortment of marketing channels (Hulme, 2010; Kamaruddin \& Samsudin, 2014; Kamyab, 2014; Adewale, 2016; Ametorwo, 2016; Obi \& Okekeokosisi, 2018; Essayyad, Palamuleni \& Satyal, 2018; Gunawardana, Tantrigoda \& Kumara, 2018). Consequently, strategic approach in realizing the appropriate tactics for the startup success is intended despite the intentions of entrepreneurs are also essential for the launching and success of startups. However, as discussed previously in the earlier section, the government has taken into account the aspirations of Indians and the collective efforts of enterprises for the success of startups in the country. Regrettably, inappropriate management 
actions of entrepreneurs were ensuing disrupted startups because of significant deviations from the expectations of a startup business in India. Therefore, following strategies would help the entrepreneurs to move in and get success in the tech startup business in India.

Deployment of government schemes - Several schemes are being introduced by the government to promote entrepreneurship in tech startups such as Atal Incubation Centers (AIC), Atal Tinkering Laboratories (ATL), Electronic Development Fund (EDF) Policy, Development of Software Technology Park (STP), and Support Center for International Patent Protection in Electronics and Information Technology (SIP-EIT). All these schemes are introduced by the government for promoting the businesses of IT services, technology hardware, enterprise software, fintech, nanotechnology, artificial intelligence, green technology, automotive technology, technology for renewable and non-renewable energy, defense, aeronautics/aerospace, business analytics, internet of things, telecommunication, networking, and clean energy (MeitY India, 2019). Entrepreneurs can avail the grants and utilize the funds through these schemes. The government is also providing support services to the tech startup entrepreneurs for raising the capital and trading of their produce. Some of these schemes are also encouraging the innovations in the country and recognizing the value of intellectual properties to capture the growth opportunities in tech startups (Ahmed, Majid \& Zin, 2016; Ali \& Haseeb, 2019; Haseeb, Abidin, Hye, \& Hartani, 2018; Haseeb, 2019; Suryanto, Haseeb, \& Hartani, 2018)

Utilization of fiscal incentives - The financial grant of the government to a tech startup in India has been starting from Rs.5 lakhs up to a maximum grant that is based on the project cost proposed by the entrepreneurs for starting of the enterprise. In some cases, the government is providing one-time funding for the establishments with a $50 \%$ grant on the plant cost and machinery without the expenditure on infrastructure and land. In addition, the existing, as well as new incubation centers in the country are also supporting the tech startups since their inception stage to total project completion stage by assisting them in production, operations, and sale of outputs. Other incentives are also providing by the government such as a refundable six months equivalent rent of the premises of the unit that has deposited by the entrepreneurs, and a refundable airfare up to $75 \%$ on business trips of entrepreneurs. Other subsidies for corporate overheads like insurance and freight charges, communication services, private transportation, printing of catalogs are also refundable as well. Banks are providing term loans for tech startups as well as releasing the reserves for working capital by cash credit or composite loans. Under various schemes, the government has been subsidizing the loans of tech startups from $12 \%$ up to $15 \%$. A tax-free income of startups also incentivized by the government up to a maximum of 5 years of the business operations. However, the fiscal incentives of the government will vary by category of tech startups.

Finding gaps in the business environment - Tech startup entrepreneurs have passion and belief in their ideas, and there are terrific tech startup ideas that executed successfully in India, but still, there are endless gaps need to address by the entrepreneurs. Because tech startup entrepreneurs have to attract their investors and they have to create confidence in their stockholders on new technologies that would help them to lead towards incredible business opportunities. However, the entrepreneur does not need any academic degree or technical educational qualification, but they should have a strong determination and knowledge to establish and control the business of a tech-based enterprise. Entrepreneurs have to develop their relationships with their business promoters as well as potential partners, employees, or journalists that would improve their public relations and give coverage to their new ideas in business. Entrepreneurs have to engage their financiers by clearly describing the technologies that are crucial for the success of their ventures in tech startups. Thus, entrepreneurs should come out of their comfort zone to get success in the launching of new technologies and innovations. Tycoons of tech-based enterprises should build a secure network of marketing strategies for success. Moreover, tech startup businesspersons have to find fresh blood with the zeal of innovative ideas who want to reach the heights in careers.

The building of minimum viable products (MVP) - MVP is testing of the technical ability of a product to meet the expectation of customers. Tech startup entrepreneurs have to conduct customer surveys to test the performance of their products before launching them in the market. Based on the outcomes of such surveys, entrepreneurs can envision the public pulse on tech-based features in their products that not only intended to incorporate in their future commercial version of products but also to decide whether to go for large-scale production or not. In the worst-case scenarios, where the majority of customers left the negative feedback on the tech-based features in the products, much work has to do by the entrepreneurs to revise the technical features of the product. By the advertisements in social media, entrepreneurs can also test the attractiveness of their products to the customers. Another option to the tech startup entrepreneurs for testing of products is customer blogs. Customer blogs provide information to potential customers, describes the technical features of products, and communicates the differential propositions of technologies that the entrepreneurs worked on creating innovative products. Business blogs are also helpful to the 
entrepreneurs to find the cofounders of what they are interested in similar technologies and to meet those people working on similar projects. By all ways, entrepreneurs would save plenty of money by not investing in tech-featured products that nobody wants to buy.

Building brand image and trust - Tech startup entrepreneurs need careful planning to attract the world by exhibiting the unique technological features in their products to create the brand image for their products. Entrepreneurs have to remember that the first taste of tech-based products is sensible to the customers because of the unique features and the differential advantages in the products that might not be offered by other competitors in the market. Entrepreneurs in tech business have to make their customers very clear about the technology propositions incorporated in their products before the positioning of the products in the market. Using flowery and straightforward language in the descriptions of products will help to develop an easy-to-read format of product specifications of tech products. Celebrity endorsements also needed for creating the brand image for tech-based products. Low pricing strategy and online marketing channels are a better fit for tech-based services. However, entrepreneurs have to collaborate with the trusted online payment facilitators or merchants. In India, $62 \%$ of smartphone users have purchased something on their mobiles during the last six months in 2018. Gathering information of customers by using secure networks is essential for managing the expectations of the customers. Therefore, creating customer-friendly e-commerce platforms and mobile apps is more advantageous to tech startup entrepreneurs to generate trust among the stakeholders.

Learning in the Tech Business - Tech startup entrepreneurs has to gain the knowledge for cleaver investments despite loose the money by risky ventures. Entrepreneurs have to search for new ideas that lead their enterprises to discover the new business models. They have to offer extraordinarily innovative and exclusive services to their customers through their rare business models. However, entrepreneurs should be more realistic during the comparisons with other technologies available in the market, but they have to keep going on achieving their goals. The successful business model of an entrepreneur should be confidential that is something all the business owners needs always. Therefore, entrepreneurs should not do everything they need to do for the growth in their business, but they have to do things differently by engaging the competitors in the market by creating awareness of new technologies. However, entrepreneurs can interact with customers and learn new things from the customers on a daily basis. For this to happen they have to create social media interaction platforms like blogs for custom formatted tweets, the building of Facebook groups, the arrangement of associations of different social media platforms, creating online facilities for the meaningful connections and relationships among collaborating firms, creation of various social media platforms to receive the feedback from the customers. These strategies will help the tech startups to grow in their business. The following section discussed the factors that stimulate this flourishing business.

\section{Factors Stimulate the Business of Tech Startups}

A startup in India is an incorporated or registered entity in the country with an annual turnover not exceeding Rs.25crore in any financial year or up to seven years after the establishment, and it works towards innovation and improvement of processes or services. The Prime Minister of India Mr. Narendra Modi has launched the startup India campaign on 16 January 2016 (see appendix for the details of the campaign) as a major initiative to encourage tech startup entrepreneurship in the country (Ministry of Commerce and Industry, 2018).

In the advent of government initiatives to promote the startup ventures in the country, total 9,183 startups including 4,400 tech startups are in the operational stage until date 15 May 2018 and more than $85 \%$ of these units registered in the services sector. According to industry estimates, the total number of tech startups will touch 12,000 by the end of 2020 (Meha Agarwal, 2017). Moreover, the Government of India had announced tax holidays for startup ventures in a more liberalized environment for raising global capital. The matters of ease of doing business and the funding of government for seed capital are frequently addressed by the government to encourage investments in the startups (Anushree Sinha, 2017). Table 2 shows the details of government funding for tech startups in various stages.

Table 2. Stage-wise deals in tech startups and the amount of funding by the government (Q1: January to March)

\begin{tabular}{lllll}
\hline Year (Q1) & \multicolumn{4}{l}{ Deals in stages (funding in billion) } \\
\cline { 2 - 5 } & Seed & Bridge & Growth & Late/Final \\
\hline 2015 & $120(0.1)$ & $110(0.1)$ & $180(0.8)$ & $199(1.5)$ \\
\hline 2016 & $205(0.2)$ & $205(0.2)$ & $262(0.7)$ & $278(1.7)$ \\
\hline
\end{tabular}




\begin{tabular}{lllll}
\hline 2017 & $155(0.2)$ & $160(0.3)$ & $215(1.0)$ & $230(2.6)$ \\
\hline 2018 & $130(0.3)$ & $125(0.3)$ & $185(0.8)$ & $190(1.2)$ \\
\hline
\end{tabular}

Source: (Ankan Das, 2018)

On the other hand, India has grown into the global destination for technology and consultancy services by allowing $100 \%$ foreign direct investment (FDI) in the technology sector. By the end of the FY18, FDI in India has reached \$62bn from \$40bn in the previous FY17 (Ramesh Abhishek, 2018). Evidence for this domestic growth of FDI is such that $60 \%$ of tech-based firms globally are using India for testing the software products before launching them in various markets. Moreover, the social, mobility, analytics, cloud (SMAC) market in India is estimated to reach \$225 billion by 2020 (The Economic Times, 2017). This enormous magnitude of business in a network of information sources around the world would democratize the spread of innovations and technologies with geographic propinquity that helped the Indian tech startups to grow further and to spread Indian based tech demanded markets worldwide (Hartley, 2012). Indeed, this business scenario would also change the face of tech startup industry in the coming years. For instance, Oyo, Ola, and Byju's are among the few tech startups that expanded their businesses worldwide. Table 3 provides the details of technology advancements in Indian tech startups that expanded in key industry segments.

Table 3. Data for 1200+ advanced tech startups expanded in key industry segments: 2013-2018

\begin{tabular}{llllll}
\hline Advanced technologies & Market share & CAGR $(5$ yrs. $)$ & Key segments & \\
\hline Data analytics & $27 \%$ & $18-20 \%$ & Enterprise & Fintech & RetailTech \\
\hline Internet of things & $26 \%$ & $15-17 \%$ & Industrial & Home Automation & HealthTech \\
\hline Artificial intelligence & $24 \%$ & $54-58 \%$ & Enterprise & Fintech & HealthTech \\
\hline $\begin{array}{l}\text { Augmented reality/Virtual } \\
\text { reality }\end{array}$ & $6 \%$ & $26-28 \%$ & EdTech & RetailTech & Real Estate \\
\hline Blockchain & $5 \%$ & $>100 \%$ & Fintech & Enterprise & AgriTech \\
\hline Others (Drones, 3D printing) & $12 \%$ & $20-25 \%$ & -- & -- & --
\end{tabular}

Source: (NASSCOM, 2018b)

Indeed, India is in third place by the number of tech startups in the world, and it is behind the USA and Britain (Ramesh Abhishek, 2018). However, few factors that stimulate the tech startup business in India are briefly discussed as follows.

Competitiveness - Startups locates in an ecosystem that comprises other startups as well as incubators, research centers at universities, investors, and added elements of business opportunities (Torres \& Souza, 2016). Overall, 140 incubators and 326 angel investors are providing collaborative services to the 4,750 startups in India, and they together created nearly 80,000 jobs in the country. Introduction of novel strategies by the government to promote tech startups and innovative practices with superior mobility and greater agility among the young startup entrepreneurs in India has created new opportunities for tech startup ventures. For the reason that the average age of startup founders in India is 28 years. Therefore, the expertise, passion, and motivation among the young entrepreneurs stimulate the business of tech startups in the country.

Information accessibility - In India, around 26\% of the population has access to the internet and India is the second largest online market with more than 462 million internet users across the country, which is the highest after China, and this number is expected to touch 640 million by 2021. According to the National Association of Software and Services Companies (NASSCOM), 730 million people will use the internet in India by 2020 (The Economic Times, 2018). However, the penetration of active mobile social media in India is only $15 \%$. Instead, the country has $76 \%$ of digital talent which is the highest proportion while comparing to the global average of 56\% (dnaindia.com, 2018). The Indian government has a strategic plan for connecting 5.5 lakh villages in the country with Wi-Fi by the end of the year 2019. This plan would cost the government to invest $\$ 555$ million (Sumit Chakraberty, 2018). Right now, the country has 340 million smartphone users, and this number is expected to reach 468 million by 2021. These plans 
of the government for the improvement of information accessibility will become an advantage for tech startups to lead their business towards success.

The growth of the IT sector - The IT industry is the principal promoter of tech startups in India. According to India Brand Equity Foundation, the market size of IT sector in India was \$74 billion in the FY10, and it touched \$154 billion in the FY17 with an annual growth rate of $11.15 \%$ (CAGR) (ibef.org, 2018). However, the IT industry would reach $\$ 350$ billion by 2025 (NASSCOM, 2018a). Besides, the IT sector is contributing nearly $8.5 \%$ of country's gross domestic product (GDP) in the FY17 that however reduced from $9.3 \%$ in the FY16 due to demonetization of currency by the Indian government on November 2016. Including hardware exports, the total exports of IT sector has increased at a CAGR of $12.84 \%$ since FY10 and reached $\$ 117$ billion in the FY17 (statista.com, 2018). As well, IT services have a significant share of $65.78 \%$ in the total IT exports whereas business process management (BPM) accounted $22.22 \%$ of share followed by other hardware and IT-enabled services together accounted the remaining $12 \%$ of share in total IT exports (statista.com, 2018). Undeniably, this growth trend of the IT sector will increase the potential of tech startup business in India.

Digital economy - Tech based companies in India has expectations that the digital economy of the country will be $\$ 4$ trillion by 2022. It is estimated by the government that digital payments in the country will cross $\$ 1$ trillion by 2023 (The Economic Times, 2017). The principal businesses subsidized for the significant portion of exports in tech-based services of India are banking, financial services, and insurance that earned the revenue of nearly $\$ 62.4$ billion in the FY17 with the 53\% of share in total exports of the IT industry. The biggest importer of Indian tech-based services is the USA that received over $62 \%$ of total tech-based exports during the FY17 followed by the UK that received $22 \%$ of tech-based exports from India. The manpower in tech-based services sector of India is such that out of 3.97 million people hired in the IT sector, $40 \%$ is recruited in the corporate sector, $30 \%$ is working in medium IT enterprises, $20 \%$ is in emerging IT enterprises, and 10\% has jobs in small IT entities (Business Standard, 2018). However, escalation of tech startups has transformed the Indian economy with primary cost competitiveness by providing the tech-based services across the globe.

Innovations - The trend of innovations in India is such that out of the total 45,444 patent applications that are filed by Indian establishments in the FY17 including tech startups, the majority, i.e., 19,640 (43.21\%) are in the fields of electrical and electronics of which the government granted 2,860 (14.56\%) patents. Whereas 14,540 (31.99\%) applications are filed in mechanical engineering and allied subjects of which 2,546 (17.51\%) were granted patents. A total of 9,510 (20.95\%) applications are filed in the chemistry and allied subjects of which 3,883 (40.83\%) were granted patents, and the remaining 1,754 (3.85\%) applications are filed in biotechnology and microbiology subjects of which the government granted 558 patents (31.81\%) (Ipindia.nic.in, 2017). Thus, by linking of innovations in the corporate sector to the increasing number of tech startup competitors in the economy has brought new resources to the ecosystem of tech startups in India (Rondani \& Colonna, 2015).

\section{Empirical Evaluation of Relationship Between Government Initiatives, Entrepreneurial Strategies and Factors Stimulate the Business of Tech Startups}

After critical evaluation of various government initiatives, entrepreneurial strategies and factors that stimulate the business of tech startups, the study carried out the analysis to test relationship of these elements with tech startup business empirically. For this purpose, a survey was performed, and data were collected from the owners of business. Total five hundred responses were collected from various business owners. After data collection, it was analyzed through PLS-SEM which is most prominent techniques to get results from surveyed data (Henseler \& Sarstedt, 2013). Figure 1 shows the measurement model of PLS-SEM which hilights the factor loadings. Table 4 shows the reliability, avrage variance extracted (AVE) and Cronbach alpha. Descriminant validity is shown in Table 5. 


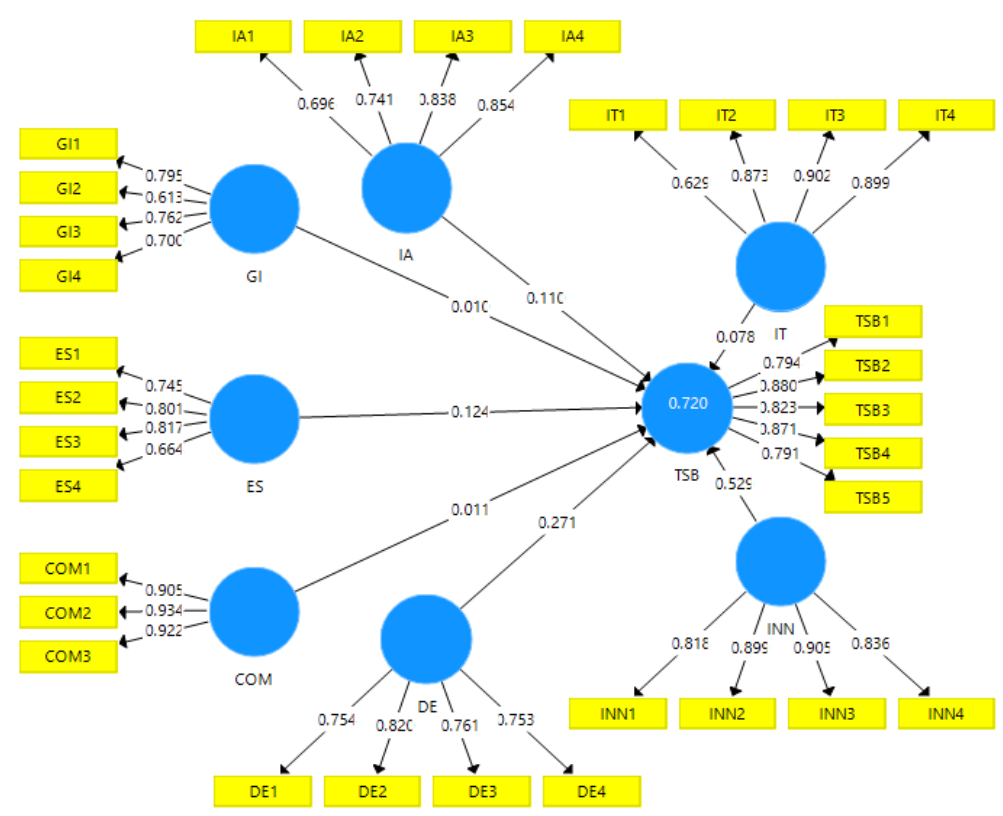

Figure 1. Measurement model

Note: $\mathrm{GI}=$ Governmental Initiatives, $\mathrm{ES}=$ Entrepreneurial Strategies, $\mathrm{COM}=$ Competitiveness, $\mathrm{IA}=$ Information Accessibility, IT = Information Technology, DE = Digital Economy, INN = Innovation, TSB = Tech Startup Business

Table 4. Measurement model results

\begin{tabular}{llll}
\hline & Alpha & Composite Reliability & (AVE) \\
\hline COM & 0.91 & 0.944 & 0.848 \\
\hline DE & 0.775 & 0.855 & 0.597 \\
\hline ES & 0.752 & 0.844 & 0.576 \\
\hline GI & 0.797 & 0.811 & 0.52 \\
\hline IA & 0.79 & 0.864 & 0.616 \\
\hline INN & 0.888 & 0.923 & 0.749 \\
\hline IT & 0.844 & 0.899 & 0.695 \\
\hline TSB & 0.889 & 0.919 & 0.693 \\
\hline
\end{tabular}

Table 5. AVE square root

\begin{tabular}{lllllllll}
\hline & COM & DE & ES & GI & IA & INN & IT & TSB \\
\hline COM & 0.921 & & & & & & & \\
\hline DE & 0.684 & 0.772 & & & & & & \\
\hline ES & 0.661 & 0.706 & 0.759 & & & & & \\
\hline GI & 0.704 & 0.767 & 0.745 & 0.721 & & & & \\
\hline IA & 0.536 & 0.677 & 0.669 & 0.603 & 0.785 & & & \\
\hline INN & 0.456 & 0.567 & 0.579 & 0.547 & 0.566 & 0.865 & & \\
\hline IT & 0.721 & 0.75 & 0.656 & 0.706 & 0.618 & 0.556 & 0.833 & \\
\hline TSB & 0.529 & 0.689 & 0.659 & 0.615 & 0.639 & 0.784 & 0.584 & 0.833 \\
\hline
\end{tabular}


Figure 2 shows the measurement model assessment which is carried out to check the relationship of government initiatives, entrepreneurial strategies and factors that stimulate the business with tech startup business.

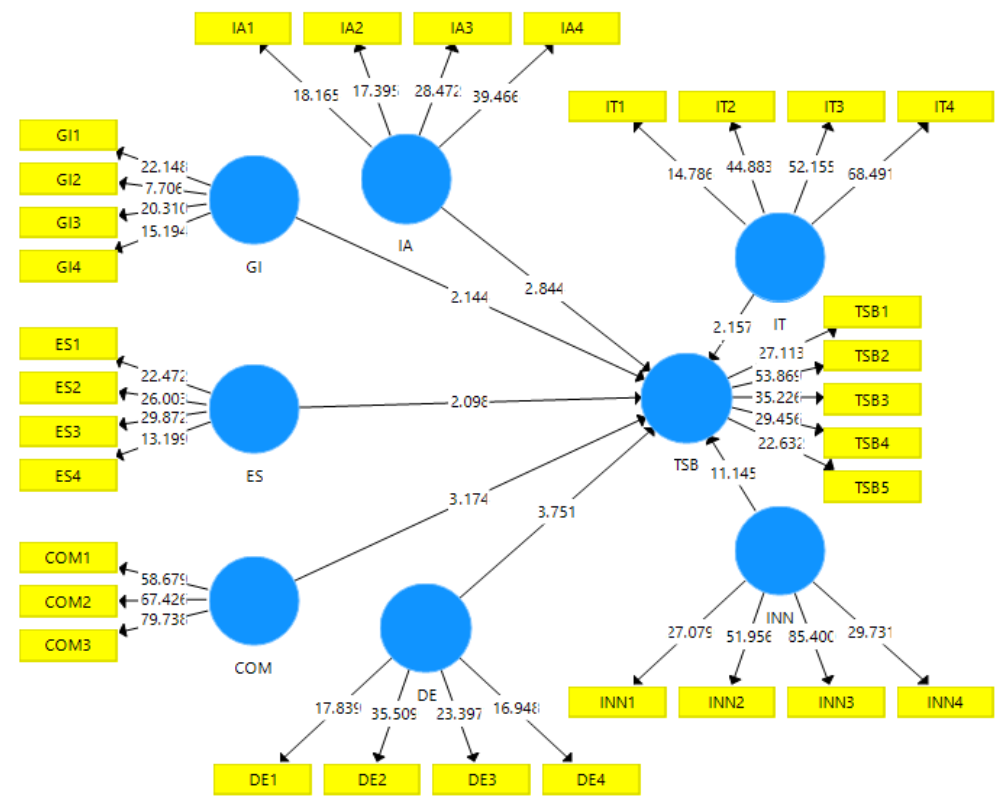

Figure 2. Relationship between government initiatives, entrepreneurial strategies and factors stimulate the business with tech startup business

Table 6. Relationship between government initiatives, entrepreneurial strategies and factors stimulate the business with tech startup business (Results)

\begin{tabular}{llllll}
\hline & Beta & $\begin{array}{l}\text { Sample } \\
\text { Mean }\end{array}$ & $\begin{array}{l}\text { Standard } \\
\text { Deviation }\end{array}$ & T Statistics & P Values \\
\hline COM -> TSB & 0.011 & 0.005 & 0.0035 & 3.174 & 0.006 \\
\hline DE -> TSB & 0.271 & 0.271 & 0.072 & 3.751 & 0 \\
\hline ES -> TSB & 0.124 & 0.124 & 0.059 & 2.098 & 0.036 \\
\hline GI -> TSB & 0.01 & 0.015 & 0.0049 & 2.144 & 0.035 \\
\hline IA -> TSB & 0.11 & 0.108 & 0.04 & 2.844 & 0.011 \\
\hline INN -> TSB & 0.529 & 0.529 & 0.047 & 11.145 & 0 \\
\hline IT -> TSB & 0.078 & 0.076 & 0.035 & 2.157 & 0.034 \\
\hline
\end{tabular}

Figure 2 and Table 6 indicates that government initiatives and entrepreneurial strategies has positive relationship with tech startup business. Moreover, factors stimulate the business such as competitiveness, information accessibility, information technology, digital economy and innovation also have positive role to promote tech startup business. Therefore, literature discussed above, and empirical findings are consistent.

\section{Conclusion}

The strategy of any startup is to grow fast in the business. Other things like technology and venture funding or sort of exit plans are the last components of strategic startup entrepreneurs (Graham, 2012). However, tech startup entrepreneurs in India are following different strategies that would help them to sustain and grow in their business. Even though the Government of India has been promoting tech startups, by funding the startup enterprises under various schemes, the entrepreneurs are also identifying ways to venture in tech-startup businesses, and they want to 
create a brand image for their tech-based products in the market. Much information is also available on startup ideas and strategies for the success of startups in India. However, this paper explicitly discussed the strategic approach of entrepreneurs in the tech startup business and deliberated the factors that stimulate the business of tech startups in India. It also exposed the initiatives of the Indian government in sponsoring tech startups in the country at large. The discussion in this paper will help the entrepreneurs to manage their tech-based businesses towards success. This debate in the paper is the clue to identify various challenges and opportunities for tech startups in the Indian tech business environment.

\section{References}

Abhishek, R. (2018). FDI: FDI in India rises to \$61.96 billion in 2017-18: Government - The Economic Times. Retrieved January 9, 2019, from https://economictimes.indiatimes.com/markets/stocks/news/fdi-in-india-rises-to-61-96-billion-in-2017-18-gover nment/articleshow/64506567.cms

Adewale, A. A. (2016). Effect of Demographic Factors on Entrepreneurial Culture: A Study of University Students in Metropolitan Kano. American Journal of Social Sciences and Humanities, 1(1), 10-34.

Agarwal, M. (2017). 50+ Startup Schemes by Indian Government For Startups.

Agbim, K. C., \& Eluka, J. (2018). Social Network and Family Business Internationalization in South Eastern Nigeria. Journal of Accounting, Business and Finance Research, 3(2), 64-74. https://doi.org/10.20448/2002.32.64.74

Ahmed, U., Majid, A. H. A., \& Zin, M. L. M. (2016). HR Moderating HR: Critical link between Developmental HR Practices and work engagement in a Moderated Model. Management Review: An International Journal, 11(2), 4.

Ali, A., \& Haseeb, M. (2019). Radio frequency identification (RFID) technology as a strategic tool towards higher performance of supply chain operations in textile and apparel industry of Malaysia. Uncertain Supply Chain Management, 7(2), 215-226. https://doi.org/10.5267/j.uscm.2018.10.004

Ametorwo, A. M. (2016). Managing Work Family Conflict among Female Entrepreneurs in Ghana for Development. International Journal of Economics, Business and Management Studies, 3(1), 21-35.

Badra, S., \& Sharma, V. (2016). Startup India - New Opportunities for the Entrepreneur. Startup India. New Opportunities for the Entrepreneur, 5(1), 4.

Balaji, S. (2017). India's Startups Are Filing More Patents than Ever Before -- Here's Why.

Baloff, N., \& McKersie, R. (1966). Motivating Startups. Journal of Business, 39(4), 473-484. https://doi.org/10.1086/294888

Bouvier, P. (2016). Ten Reasons Why Fin Tech Startups Fail.

Bugu, Z. Y., \& Yucheng, H. (2018). An Empirical Analysis of the Factors Affecting the Profitability of China's Agricultural Listed Companies under the Background of Agricultural Modernization. International Journal of Applied Economics, Finance and Accounting, 2(1), 19-26. https://doi.org/10.33094/8.2017.2018.21.19.26

Business Standard. (2018). Good times ahead for Indian techies! IT sector to hire over 100,000 people. Business Standard News.

Chakraberty, S. (2018). India has 462 million internet users; $79 \%$ traffic is mobile.

Das, A. (2018). Indian Tech Startup Funding Report Q1 2018. Retrieved January 9, 2019, from https://inc42.com/datalab/indian-tech-startup-funding-report-q1-2018-1-17-bn-invested-across-196-deals/

Department of Ministry of Commerce and Industry, Government of India. (2018). Startupindia. Retrieved from startupindia.gov.in

DNA. (2018). India's digital talent is 76\%; global average is 56\%: Study. Retrieved from dnaindia.com

Eschenfelder, A. D., \& Holstein, M. J. (2017). Economic Analysis of Public Support for Tech Startups: a Case Study of Pittsburgh. Journal of Business and Behavioral Sciences, 29(1), 100-116.

Essayyad, M., Palamuleni, M., \& Satyal, C. (2018). Remittances and Real Exchange Rates in South Asia: The Case of Nepal. Asian Economic and Financial Review, 8(10), 1226-1238.

Graham, P. (2012). Startup = Growth .

Gunawardana, H., Tantrigoda, D. A., \& Kumara, U. A. (2018). Integrating Sustainable Land Management for 
Post-Conflict Economic Recovery. Asian Development Policy Review, 6(3), 129-141.

Hartley, S. (2012). Tech Startups in Africa - Forbes.

Haseeb, M., Abidin, I. S. Z., Hye, Q. M. A., \& Hartani, N. H. (2018). The Impact of Renewable Energy on Economic Well-Being of Malaysia: Fresh Evidence from Auto Regressive Distributed Lag Bound Testing Approach. International Journal of Energy Economics and Policy, 9(1), 269-275.

Haseeb, H. Z. G., Hartani., N. H., Pahi, M. H., \& Nadeem., H. (2019). Environmental Analysis of the Effect of Population Growth Rate on Supply Chain Performance and Economic Growth of Indonesia. Ekoloji, 28(107).

Henseler, J., \& Sarstedt, M. (2013). Goodness-of-fit indices for partial least squares path modelling. Computational Statistics, 28(2), 565-580. https://doi.org/10.1007/s00180-012-0317-1

Hulme, T. (2010). Evaluating Startups. HackFwd Blog. Available at: http://blog.hackfwd.com/post/6754934.

India Brand Equity Foundation. (2018). IT \& ITeS. New Delhi, India. Retrieved from ibef.org

Isimoya, O. (2014). Business ethics in insurance industry in Nigeria. International Journal of Management and Sustainability, 3(6), 341.

Iyiola, O. (2014). Supporting Tourism Business in Nigeria via Integrated Marketing. Journal of Tourism Management Research, 1(2), 27-39. https://doi.org/10.18488/journal.31/2014.1.1/31.1.27.39

Kamaruddin, R., \& Samsudin, S. (2014). The sustainable livelihoods index: A tool to assess the ability and preparedness of the rural poor in receiving entrepreneurial project. Journal of Social Economic Research, 1(6), 108-117.

Kamyab, S. H. (2014). The Entrepreneurship, Knowledge Spillover and Economic Growth. International Journal of Sustainable Development \& World Policy, 3(2), 45-54.

Kurup, R. (2018). Patents filings prove Indian start-ups are no longer copycats - The Hindu BusinessLine. Retrieved January 25, 2019, from https://www.thehindubusinessline.com/info-tech/patents-filings-prove-indian-start-ups-are-no-longer-copycats/a rticle22671179.ece

Lasso, S., Mainardes, E., \& Motoki, F. (2017). Why do entrepreneurs open tech startups? A comparative study between Brazilian and foreign enterprises. International Entrepreneurship and Management Journal, 1-23. https://doi.org/10.1007/s11365-017-0445-8

Madden, A. (2005). Funding of Innovative Startups. Technology Review, 108(6), 32.

Make In India. (2018). Information Technology. Retrieved from Makeinindia.com

Maldonado-Guzman, G., Pinzon-Castro, S. Y., \& Rodriguez-Gonzalez, R. M. (2018). Brand Management, Competitiveness and Business Performance in Mexican Small Service Businesses. International Journal of Asian Social Science, 8(10), 898-908. https://doi.org/10.18488/journal.1.2018.810.898.908

MeitY India. (2019). Functions of Ministry of Electronics and Information Technology. Ministry of Electronics and Information Technology, Government of India. Retrieved January 25, 2019, from http://meity.gov.in/about-meity/functions-of-meity

Ministry of Commerce and Industry, Government of India. (2018). Startupindia, Department of Ministry of Commerce and Industry, Government of India.

Ministry of Electronics and Information Technology, Government of India. (2012). National Policy on Information Technology. New Delhi, India. Retrieved from Meity.gov.in

NASSCOM. (2018a). Imperatives for a Digital Ready India. NASSCOM.

NASSCOM. (2018b). Indian Tech Start-Up Ecosystem 2018: Approaching Escape Velocity. Retrieved January 9, 2019,

from https://www.nasscom.in/knowledge-center/publications/indian-tech-start-ecosystem-2018-approaching-escapevelocity?destination $=$ node $/ 3603$

Obi, M. N., \& Okekeokosisi, J. (2018). Extent of Implementation of National Entrepreneurship Curriculum in Tertiary Institutions as Perceived by Educators. American Journal of Education and Learning, 3(2), 108-115.

Okafor, C., \& Shaibu, I. (2016). Modelling Economic Growth Function in Nigeria: An ARDL Approach. Asian Journal of Economics and Empirical Research, 3(1), 84-93. 
Prashantham, S., \& Yip, G. S. (2017). Engaging with startups in emerging markets. MIT Sloan Management Review, $58(2), 1-9$.

Rey, J. D. (2013). Funding tech startups-good for agencies, but what about clients?. Advertising Age, 84(8), 16.

Rondani, B., \& Colonna, C. (2015). Open Startups: connecting startups to corporate innovation strategies. $R \& D$ Management - (Fast?) Connecting R\&D, 1-10.

Scarmozzino, E., Corvello, V., \& Grimaldi, M. (2017). Entrepreneurial learning through online social networking in high-tech startups. International Journal of Entrepreneurial Behavior \& Research, 23(3), 406-425. https://doi.org/10.1108/IJEBR-12-2015-0302

Sinha, A. (2017). Building Synergies: Matching Business Reforms to Improved "ease of doing business". New Delhi, India.

Sinha, G. (2008). Strategies for Startup Success. Siliconindia, 11(9), 44-45.

Statistic. (2018). Indian IT-BPM industry GDP share 2009-2017. Retrieved from statista.com

Suryanto, T., Haseeb, M., \& Hartani, N. H. (2018). The Correlates of Developing Green Supply Chain Management Practices: Firms Level Analysis in Malaysia. International Journal of Supply Chain Management, 7(5), 316.

Team Inc42. (2018). 2018 in Review: 10 of the Biggest Startup Failures in India. Retrieved January 9, 2019, from https://inc42.com/features/2018-in-review-10-of-the-biggest-startup-failures-in-india/

The Economic Times. (2017). Assocham: Indian ICT revenue to touch $\$ 225$ billion by 2020: Assocham.

The Economic Times. (2018). 730 million Internet users anticipated in India by 2020: Manoj Sinha. ET Telecom.

The Office of the Controller General of Patents, Designs, Trade Marks and Geographical Indications, Government of India. (2017). Intellectual Property India, Annual Report 2016-17. New Delhi, India. Retrieved from Ipindia.nic.in

Torres, N. N. J., \& Souza, C. R. B. (2016). A Literature Review About Technology Startups Ecosystems. In Proceedings of the XII Brazilian Symposium on Information Systems on Brazilian Symposium on Information Systems: Information Systems in the Cloud Computing Era (Volume 1, pp. 385-392).

Udanoh, M. U., \& Zouria, A. (2018). Using Gender Inequality to Predict the Rate of African Women Entrepreneurship. International Journal of Emerging Trends in Social Sciences, 3(1), 17-28.

WIPO. (2018). Number of patents granted by India shot up by 50\% in 2017: UN. Retrieved January 25, 2019, from https://economictimes.indiatimes.com/news/economy/finance/number-of-patents-granted-by-india-shot-up-by-5 0-in-2017-un/articleshow/66932638.cms

Wye, C. K., \& Lim, Y. M. (2014). Analyzing Skill Profile Among Business Graduates: Is it Generic or Specific?. International Journal of Business, Economics and Management, 1(5), 57-71.

Zhong, H., Liu, C., Zhong, J., \& Xiong, H. (2018). Which startup to invest in: a personalized portfolio strategy. Annals of Operations Research, 263(1-2), 339-360. https://doi.org/10.1007/s10479-016-2316-z

\section{Appendix: Startup India Campaign}

'Startup India' is one of the campaigns of Government of India initiatives to promote entrepreneurship in the country (startupindia.gov.in, 2018). The startup India initiative aims to nurture the innovations and drive the sustainable economic growth of the country by generating employment opportunities at large scale. Subsequently, after the campaign was started from January 2016, the restrictions of State government policies in India for entrepreneurial activities have been discarded such as license raj, land permissions, environmental clearances, and foreign investment proposals. However, every state has their initiatives to promote startups in their regions. For instance, Kerala state has the startup promotion policy called 'Kerala IT mission.' Telangana has 'T-Hub,' and Rajasthan has launched 'Start-up Oasis' scheme. Equally, the central government has an action plan intended to develop a healthy ecosystem for startups in India. The action plan of the government has focused on how to reduce the burden of regulatory formalities for enterprising startups to make the compliance friendly for flexible business operations in the country. The action plan has also emphasized the incentives for funding support to startups as well as for the development of partnerships between industry and academia by establishing incubation centers across the country. 